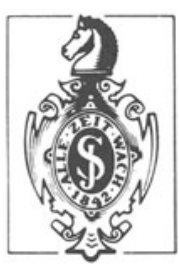




\section{Infant Feeding}

Anatomy of a Controversy 1973-1984

Edited by John Dobbing

With a Foreword by Frank Falkner

Springer-Verlag

London Berlin Heidelberg New York

Paris Tokyo 
John Dobbing, DSc, FRCP, FRCPath

Emeritus Professor of Child Growth and Development, Department of Child Health, University of Manchester, Oxford Road, Manchester M13 9PT, UK

British Library Cataloguing in Publication Data

Infant feeding: anatomy of a controversy

1973-1984.

1. Babies. Artificial food. Marketing

I. Dobbing, John, 1922-

$664^{\prime} .62^{\prime} 0688$

ISBN 978-1-4471-1620-2

Library of Congress Cataloguing-in-Publication Data

Infant feeding: anatomy of a controversy, 1972-1984 / John Dobbing.

p. $\quad \mathrm{cm}$.

Bibliography: p.

Includes index.

ISBN-13: 978-1-4471-1620-2

DOI: 10.1007/ 978-1-4471-1618-9

e-ISBN-13: 978-1-4471-1618-9

1. Nestlé Alimentana Company. 2. Baby foods industry-Developing

countries. 3. Infants-Developing countries-Nutrition. 4. Infant

formulas-Health aspects. I. Dobbing, John.

HD9015.S93N448 1988

$338.7^{\prime} 66462^{\prime} 0917-\mathrm{dc} 19$

This work is subject to copyright. All rights are reserved, whether the whole or part of the material is concerned, specifically the rights of translation, reprinting, reuse of illustrations, recitation, broadcasting, reproduction on microfilms or in other ways, and storage in data banks. Duplication of this publication or parts thereof is only permitted under the provisions of the German Copyright Law of September 9, 1965, in its version of June 24,1985 , and a copyright fee must always be paid. Violations fall under the prosecution act of the German Copyright Law.

(C) Springer-Verlag Berlin Heidelberg 1988

Softcover reprint of the hardcover 1 st edition 1988

The use of registered names, trademarks etc. in this publication does not imply, even in the absence of a specific statement, that such names are exempt from the relevant laws and regulations and therefore free for general use.

Product Liability: The publisher can give no guarantee for information about drug dosage and application thereof contained in this book. In every individual case the respective user must check its accuracy by consulting other pharmaceutical literature.

Filmset by Wilmaset, Birkenhead, Wirral 


\section{Foreword}

This book is about a controversy which fascinated the medical and scientific world, as well as national and international health authorities, politicians, religious groups and consumer organisations, for more than 11 years. The controversy often disturbed public opinion, being concerned as it is with nothing less than the life and death of babies. It is a story which is full of confrontations, intrigue and passionately-held opinions, based nevertheless, on a sizeable body of medical science. After countless twists and turns it has some sort of "happy-ending". Yet a great deal remains to be said, as will be seen throughout the account which follows.

As is so often the case, great issues often go unrecognised in their early stages. This particular one began with an article The Baby Food Tragedy published in August 1973 in a little-known journal. It was pre-circulated to health professionals, soliciting comments from them so that a public campaign could be launched to draw attention to "a continuing scandal"'.

The infant food industry was directly accused of having caused a decline in breast-feeding through the inappropriate marketing of breast milk substitutes. The problem was said to be particularly acute in poor under-developed world communities, because illiterate mothers were unable to understand instructions for its use, water was often contaminated, and in order to "stretch" an admittedly expensive product, it was over-diluted. The inevitable result, said the critics of industry, was malnutrition, gastroenteritis and increased infant mortality.

These were very serious charges against companies which had until then been generally considered to provide an important contribution to medical progress and child health. One company was to be particularly singled out: Nestle SA, the Swiss multinational, with its headquarters in the little lakeside town of Vevey where it was founded more than 120 years ago. Perhaps it became the target because it was the longest established, and served well as a symbol of the whole industry.

At first, the accusations levelled at the Company seemed absurd yet, at the same time, they were so potentially damaging for its reputation that they resulted in a law suit in a Swiss Court. Soon, however, it became apparent that matters were not that simple. This book gives an interesting account of the Bern trial, at which Nestlé 
sued Swiss activists for libel on the publication of a pamphlet entitled Nestlé tötet Babys ("Nestlé Kills Babies"). One of the fascinating features of the law suit was that although the Company won a legal victory, it was itself, rather than the defendants, who appeared to be on trial.

Later the issue was to escalate through a flood of publicity and happenings. Reports, statements, films, investigations, demonstrations, boycotts, followed in close succession. Congressional hearings in Washington, chaired by a well-known political leader, were followed by a series of international meetings under the auspices of the World Health Organization (WHO) and UNICEF, which led to the adoption by the World Health Assembly of an unprecedented international Code.

By this time the controversy had reached a point where even this important involvement of UN agencies failed to bring it to an end. The activists' attacks went on. They began listing a large number of alleged violations by Nestlé and others, and thereby kept the boycott alive. Faced with this inextricable situation, the Swiss Company made an innovative move in Spring 1982: it funded the creation of an independent Infant Formula Audit Commission, chaired by former US Secretary of State, Senator Edmund S. Muskie. The commission was to advise the Company on its procedures for implementing the WHO Code, and to investigate complaints raised by concerned groups or individuals related to its marketing activities in the infant feeding field. The impartial work of the Commission's distinguished members was probably more decisive than any other factor in bringing the conflict to its resolution.

This book does an excellent job of describing the long and eventual controversy. Having myself been an attentive observer throughout, I found in it the explanation for many hitherto unanswered questions, as well as plenty of food for thought. Two things remain foremost in my mind. First, that infant feeding is a highly complex, scientific subject with a mind-boggling mass of inter-related factors, especially when viewed in the multicultural context of the international arena. The book illustrates how vast the problems can become when seen from the particular vantage points of widely disparate interests such as industry, consumer advocates, churches, politicians and journalists. It highlights what strikes me as a remarkable and consistent lack of serious analysis by the activists throughout the controversy. Occasionally, the text implies that industry and Nestle found themselves unfairly accused. I must say, however, that as a whole, the book appears to me to be restrained, based on historical and scientific facts, and to avoid polemics.

Secondly, I am staggered by the time and resources spent by so many people over these eleven years to achieve the end-result described in the last chapter: arguably the book's best. It is all the more astonishing when it is realised that basically there was never any disagreement on the essential point: every single party involved held the central tenet that breast-feeding is far superior to any other form of feeding during the first months of life. 
At the same time, everyone knows that "wars" are extremely costly, and this one was no exception. Yet, I believe some good did come out of it all. The WHO International Code of Marketing of Breast Milk Substitutes gave and continues to give guidance to governments as to how health services, health professionals, industry and consumer groups can work together, in the context of its specific aim "to contribute to the provision of safe and adequate nutrition for infants". Few governments seem to have done very much to implement the code they approved, and some observers have therefore asked whether its formulation was not rather a lot of fuss about little. Such sceptics fail, however, to take into account the usefulness of the controversy as a precedent and the importance of the lessons which have been learned by all concerned.

First of all, Nestlé itself shows that it has gained a much deeper understanding of its role as a leading manufacturer in this sensitive area, having committed its operating companies to respect the aim and principles of the Code to the letter. In this way it has set an example for the entire industry, and this has come to be recognised by some of the Company's severest critics. It is hardly likely, however, that such a Code could have been conceived and born without the efforts of the critics of Industry. Nor should it be forgotten that the good which has come of the Code results from a coming together of the differing points of view of the parties concerned: industry and activists, scientists and government authorities. This could never have been the result had the original, somewhat negative, demands of the critics been accepted blindly.

These very important lessons have their application well beyond the field of infant feeding. They ought to serve as a model for resolving, at a lower cost in terms of energy, resources and emotions, the wider problems caused by poverty, poor nutrition and health care, and lack of hygiene, which threaten the life and future of children in the developing world and elsewhere.

In such a spirit of conciliation the controversy should not be seen as a wasteful experience, and this thought-provoking and honest attempt to describe the experience of industry, through the example of Nestlé, will hopefully contribute to better understanding in the interest of us all.

Berkeley, California

Frank Falkner, MD, FRCP

December 1987 


\section{Preface}

Throughout a long career in medical scientific research I have constantly been motivated by an interest in the impact of medical science on the more widespread contemporary problems of human beings, as well as by a fascination with my own special scientific subjects. Thus my work on the growth and development of the fetus, of the baby and of the older child, and especially of the brain during this time, has mostly centred on the possible deleterious effects of developmental undernutrition, itself inseparable from the whole ecology of human poverty.

In all of this, and in addition to making one or two minor discoveries, I must confess to having often been temperamentally attracted by the task of trying to correct those whose similar interests have sometimes, in my view, led them away from reasonable scientific truth and proper social application. Thus I must admit to having frequently enjoyed denouncing, as well as creating. Examples have been my reviews, often somewhat polemical, of such diverse topics as the blood-brain barrier, maternal nutrition in pregnancy, early nutrition and later achievement, a cell number/cell size theory of tissue growth and development, and, latterly, of the very great importance (in which I passionately believe) of breast-feeding, in indigent society as elsewhere.

It is scarcely surprising, therefore, that in the last twenty years at least I have keenly followed both the developing scientific background as well as the wider social and commercial context of the "infant food" controversy which is the subject of this book, an interest first stimulated in me in 1966 by a sojourn in Kampala, Uganda. While there I was in close and admiring contact with Dr. Derrick Jelliffe, who was Professor of Paediatrics in Uganda at the time, and with Dr. Roger Whitehead, who was then deputy director of the Medical Research Council Unit next door, investigating infant malnutrition.

Since then the subject has embraced even wider issues still, leading to the famous World Health Organization meetings between 1979 and 1981, which produced the Code of Marketing of Breast Milk Substitutes, which I attended throughout, and which continue to occupy the energies of a wide range of activists, both my kind and those with even firmer roots in the social politics of both Third World and "First" World current affairs. 
From what I have written it will now be quite readily appreciated why the subject appeals to me, both scientifically and temperamentally. Here is a topic in which the participants have argued long and loud, pulling no punches, and having recourse to a basis of scientific fact, and sometimes belief, in an area which I have adopted as one of my own.

Until the appearance of this book, almost everything which may be found on the library bookshelves has come from one sida of the fence, a side which I have called "activist". I believe that is a misleading name, since I too am an activist, as must anyone be who feels strongly and takes action about something, as well as knowing some of the facts. I have long thought that the time has come when an attempt should be made to put the whole matter in a better perspective. It is one of the purposes of this book to do so, and for the record.

It has been my long-standing belief that the whole foundation of the controversy, commercial or political, is the medical science of the matter. Without that there would be no argument. I also believe that all sides have too often neglected this foundation in their quarrels, especially the lay militants who have so far written nearly all the books and pamphlets; but also, to some extent, the infant food industry itself, which has quite reasonably been more immediately concerned with the impact on their markets. That is why I have given pride of first place to the medical science in this book, and a few words should now be said on this.

Medical science is rarely exclusively factual, concerned as it eventually is with the impenetrable nature of life itself. This does not separate it from other kinds of science, which, at their frontiers, are equally speculative. In other words science must include opinion, but to be of any value that opinion must be based on an honest appraisal of the known "facts", and not on a distortion of them. Now it must be accepted that all scientists distort their facts, since all scientists worth their salt have motivation which guides them, and this applies to even the most "scientific" of endeavours. If science were simply a matter of ascertainable fact, then our task in setting out the medical science of our present subject would be easily accomplished, and would be decisive in the argument.

The best that can honestly be offered is a reasonable interpretation of the few "facts" which are available, and a collation of responsible opinion about them, in a form which the interested reader, whatever his background, can sufficiently assimilate for the purpose of making up his own mind.

Our book is not, however, exclusively an account of the physiology or sociology of infant feeding. It is mainly a history of a world-wide controversy, involving the infant food industry, medical scientists and certain activist movements. All the large manufacturers of breast milk substitutes (as they came to be called) were involved, and prominently the Nestlé Company, with whom I have had most contact. Several prominent medical scientists actively supported one side or another; while those very many people in many countries who followed the leading activists, and lent them support, were mainly ordinary, well- 
intentioned people. In enormous numbers they are daily appalled by the obscenity of world poverty and the ways in which children, especially, are afflicted by it. It is for them, as well as for paediatricians and other health professionals, including those responsible for organising the health services, that I decided to put this book together.

As I have said earlier, it begins with an account of the medical science, since it is this which is at the heart of the matter. Medical facts, as we shall see, have often been rearranged to serve the requirements of polemics. However, although I feel reasonably qualified to discuss the medical and scientific aspects, I was less confident when it came to things which concern the media, politics, international affairs and public attitudes. This is why I have been fortunate to benefit from the work of two specialists in the art of communication in producing the book. Both had independently studied the history of the controversy, each from their own viewpoint. Maggie McComas is an American business writer and public affairs analyst who first developed an interest in the controversy while conducting research for a study on Europe's consumer movement. Chapters 3 to 7 are based on a report she wrote in 1981. Gabriel Veraldi is a well-known French writer who has long been interested in what in 1958 he first called "l'humanisme technique". In this way the reader is presented with perspectives from the New, as well as the Old World, and this is quite appropriate to an affair which unfolded on both sides of the Atlantic.

My hope is that, as well as redressing the balance on the library shelves on which there is mainly a one-sided representation at present, our book may also interest newcomers to the subject, including those with a lay, as well as a professional, interest in the way a free society handles these sorts of problem, which surely concern us all.

I wish to thank my fellow contributors; my publishers; and the Nestlé Company, who have readily opened their doors, as well as their filing cabinets, to assist us in our task, even when they have occasionally not agreed with us.

St Julien de Cénac

John Dobbing January 1988 


\section{Contents}

Contributors ................................................... xvii

\section{The Charges}

G. Veraldi ............................................................. 1

"Breast is Best" ........................................................ 1

Decline in Breast-Feeding ................................... 2

The Vast Majority of Mothers Can Breast-Feed ................. 3

Health Hazards of Feeding Breast Milk Substitutes .............. 3

Infant Formula a Drain on National Resources ................. 5

Infant Formula Marketing …................................ 5

\section{Medical and Scientific Commentary on Charges made} against the Infant Food Industry

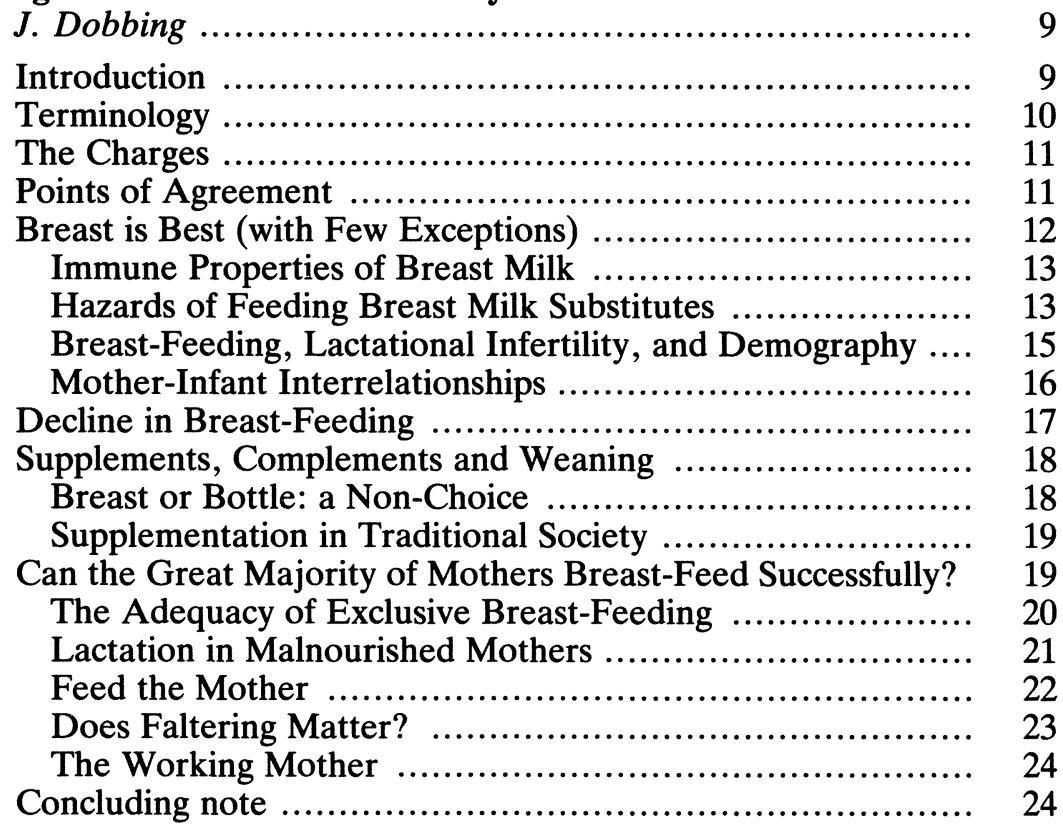


3. Origins of the Controversy

Maggie McComas ................................................ 29

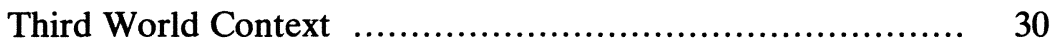

Feed the Mother .......................................... $\quad 30$

Industry Participation ....................................... 31

PAG Statement No. 23 ........................................ 33

ICIFI: Formalising Industry Cooperation $\ldots \ldots \ldots \ldots \ldots \ldots \ldots \ldots . . . \ldots \ldots$

The Debate Goes Public ....................................... 35

The New Internationalist Report ............................ 36

The Baby Killer ................................................ 38

Policy Review ............................................. 40

4. Focus on Nestlé: The Bern Trial

Maggie McComas ............................................ 43

Naming Nestlé .................................................. 44

The Swiss Activists ........................................... 44

Identifying the Activists .................................... 45

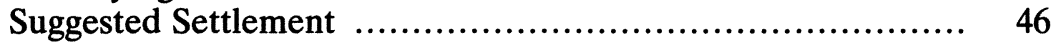

Defendant's Public Relations Strategy ......................... 46

Reduced Charges .............................................. 47

Courtroom Testimony ......................................... 48

Nestlé Press Conference ....................................... 49

Written Testimony ........................................... 50

Back to the Courtroom ....................................... 51

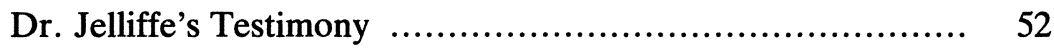

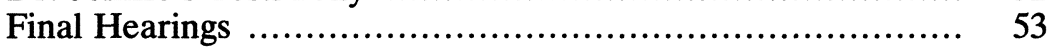

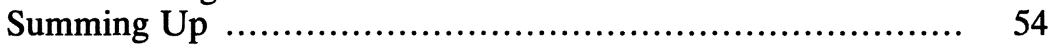

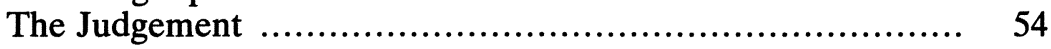

5. The US Campaign

Maggie McComas ............................................. 57

Religious Groups' Support ................................... 57

Shareholder Resolutions ..................................... 58

Shareholders Go To Court ..................................... 59

Nestlé in the US .............................................. 60

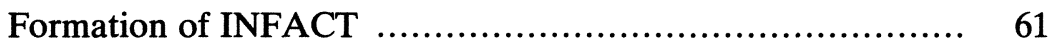

Launch of the Boycott ...................................... 61

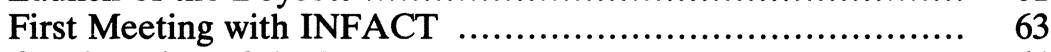

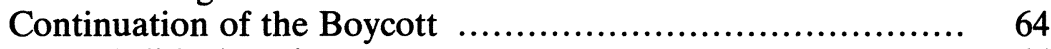

Next: Political Action ....................................... 66

6. Into the Political Arena

Maggie McComas ............................................. 67

Importance of Hearings ........................................ 67

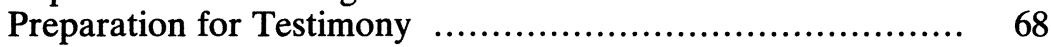

Choosing a Spokesman .......................................... 69

Questionable Credentials ....................................... 69

Fateful Statement ........................................... 71

Result of Hearings ........................................... 72 
Follow-Up Meeting ................................................. 74

Into the Mouths of Babes ...................................... 75

ICIFI Enters the Scene ................................................ 76

Confrontation with the National Council of Churches ........... 77

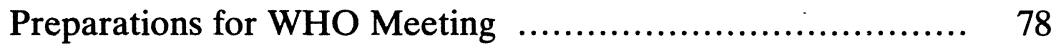

7. Developing International Recommendations: the WHO

\section{Code}

Maggie McComas ...................................................... 81

WHO Programme ................................................... 81

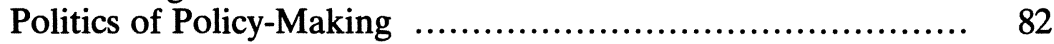

Planning the Meeting …........................................ 83

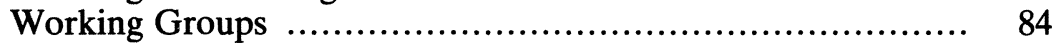

Consensus on Marketing …................................... 85

Nestlé's Response .......................................... 86

Nestlé's Checklist for Marketing Practices …................ 87

Activists Resurgent .......................................... 88

Development of ICIFI Model Code ............................ 89

Industry "Violations" ........................................ 90

Difficult Drafting Job ....................................... 91

Regulation or Recommendation? ......................... 92

8. Escalation of the Campaign and Nestlé's Response

G. Veraldi ...................................................... 95

Escalation: Further Observations on the Controversy from Industry's Standpoint .............................................. 95

The Power of a Simple Message …........................... 96

Playing on the Emotions ............................................ 96

Professional Endorsement ............................... 98

Church, Politics and Press ................................. 99

Nestle's Response ........................................ 102

Development of Product and Marketing Policy .................. 103

Emphasis on Breast-Feeding ................................ 103

Mothercraft Activities ..................................... 105

Medical Representatives ................................. 107

Product Sampling and Free Supplies to Hospitals ............ 108

Safety in Preparation and Feeding .......................... 109

Protecting Vulnerable Consumers ................................. 109

United Methodist Task Force ................................ 110

9. Implementing the WHO Code

G. Veraldi ........................................................... 115

ICIFI Disbanded ...................................................... 115

Dialogue with the United Methodists ............................ 116

Code Implementation at the National Level ...................... 118

The Nestlé Instructions .................................................. 120

Audit Committee ........................................................... 121

Nestlé Announces its New Policy ..................................... 122

Interpreting the WHO Code .................................... 124 
Revising the Nestlé Instructions …............................. 128

Support for the Boycott Wanes ............................. 130

\section{Resolution of the Conflict}

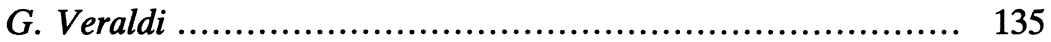

The "Four" Points ............................................ 136

January 1984 Discussions ...................................... 137

Nestlé Statement of Understanding ............................ 140

Nestlé/INBC Agreement ....................................... 142

Boycott Suspension …...................................... 143

Termination of the Nestlé Boycott ........................... 145

11. Epilogue

J. Dobbing ................................................... 149

Appendix 1. The Nestlé Infant Formula Audit Commission -

(NIFAC) Charter ......................................... 153

Appendix 2. Nestlé Statement of Understanding .............. 156

Appendix 3. Addendum to the Nestlé Statement of Understanding ............................................ 161

Subject Index ................................................ 165 


\section{Contributors}

John Dobbing, DSc, FRCP, FRCPath, the editor, is Emeritus Professor of Child Growth and Development in the Department of Child Health, University of Manchester. As a practitioner and professional medical research worker in several fields of paediatric research, he has taken a special interest in the infant food controversy. He has published several books and many papers, and edited the leading reference work Scientific Foundation of Paediatrics (Heinemann, London, 1981).

Frank Falkner, MD, FRCP, who introduces the book, is Professor and Program Head, Maternal and Child Health Program, University of California, Berkeley. He was elected senior member of the Institute of Medicine of the National Academy of Sciences in 1985 in recognition of his distinguished work in the study of human biology and international child health.

Maggie McComas is an American business writer and public affairs analyst. She first developed an interest in the infant food controversy whilst working on the study, Europe's Consumer Movement: Key Issues and Corporate Responses (Business International, Geneva, 1981). She is a former associate editor of Fortune magazine and is now a free-lance writer based in New York City.

Gabriel Veraldi is a French novelist and investigative journalist who has had a long-standing interest in the relationship between industry and society (L'humanisme technique, 1958), as well as in development issues. He was once a close associate of Josué de Castro, a former Director General of the UN Food and Agriculture Organisation (FAO). He has been studying the infant feeding controversy since 1981 , in the context of a book to appear shortly, L'industrie, l'information et les mythologies modernes. 